Indonesian Journal of Biotechnology, December, 2011

Vol. 16, No. 2, pp.83-87

\title{
CYP3A4*1G gene Polymorphism on Javanese People
}

\author{
Em Sutrisna ${ }^{1,2 *}$, Iwan Dwiprahasto ${ }^{3}$, Indwiani Astuti ${ }^{3}$, and Erna Kristin ${ }^{3}$
}

\begin{abstract}
${ }^{1}$ Doctoral Program of Medical and Health Science, Faculty of Medicine, Universitas Gadjah Mada, Yogyakarta, Indonesia,

${ }^{2}$ Faculty of Pharmacy, Muhammadiyah University of Surakarta, Surakarta, Indonesia

${ }^{3}$ Department of Pharmacology and Toxicology, Faculty of Medicine Universitas Gadjah Mada, Yogyakarta, Indonesia
\end{abstract}

\begin{abstract}
Abtract
Most of drugs are metabolized by cytochrome P 450 (CYP) enzyme. Cytochrome P450 3A4 is the cytochrome that is involved in metabolizing more than $60 \%$ of all medicine used in human. The variation of this CYP3A4 gene will affect the catalytic activity of this enzyme. Recently, CYP3A4*1G in intron 10 was found in Chinese and Japanese population. There is a substitution of $G$ to $A$ at position 82266 in intron 10 . The purpose of this research was to investigate the frequency of allele and genotype CYP3A4*1G. Samples were taken from bloods of the subjects of the research. The examination of CYP3A4* $1 G$ was conducted by RTLP-PCR method.As the results of this research, the frequency of $C Y P 3 A 4^{*} 1 G$ in Javanese people is CYP3A4* $1 /{ }^{*} 10.25$, CYP3A4 ${ }^{*} 1 /{ }^{*} 1 G 0.55$ and CYP3A4 ${ }^{*} 1 G /{ }^{*} 1 G$ 0.20. Frequency of allele G: 0.53 , allele A: 0.47 . The Fisher's exact- test shows that the allele and genotype frequencyis p. 1.000. The allele and genotype frequency of Javanese people isstill in Hardy-Weinberg equilibrium.
\end{abstract}

Keywords : CYP3A4*1G gene, polymorphism, Javanese people

\section{Introduction}

The response to drugs delivery is influenced by many factors. These factors included drug's factors and host factors. Host factors that affect clinical response are age, nutritional status, and physiologic organs including genetics factors. Genetic variation that currently focused on attention is genetic polymorphism in individual that leads to differences in treatment response. Polymorphism in individual can influence the pharmacokinetic profile of drugs, including absorption, distribution, metabolism and elimination. This happens because these polymorphism can cause level of drugs does not achieve the expected therapeutic

*Corresponding Author:

Em Sutrisna

Faculty of Pharmacy, Muhammadiyah University of Surakarta, Jl. A.Yani Tromol Pos 1 Pabelan, Surakarta, Indonesia

E-mail: em_sutrisna@yahoo.com levels (sub therapeutics), or even cause toxic therapeutics. Sub therapeutic levels can cause the treatment failure and toxic therapeutics level can lead to excessive drugs effect (Alvirevi et al, 2006)

CYP3A4 enzyme is present in liver and gastrointestinal tract (Tomaszewski et al., 2008; Hsieh, et al., 2001) and inrenal dan prostatparencim (Tomaszewski et al., 2008). Human liver caontains the most abundant isoenzyme of CYP450 (Gao et al., 2008). It has 18 isoform numbers with a molecular weight of $57,1 \mathrm{kD}$ (Tomaszewski et al., 2008). CYP3A4 is involved in the metabolism of more than $50 \%$ of drugs in human (Van Schaik et al., 2000 ; Wang et al., 2005), among of these are alprazolam, amiodaron, amlodipin, amitriptilin, atorvastatin, deksametason, dektrometorpan, diazepam, digoksin, diltiasem, ketokonazole, ondansentron, terfenadin, progesterone, nateglinid and others (Tomaszewski et al., 2008). 
Polymorphism can be found on the enzyme of drugs metabolism gene, drugs traport gene, and drugs target gene. Polymorphism that is most widely mapping is on drug metabolism gene. Most of drugs are metabolized by cytochrome P450 (CYP). From the various CYP that has been mapped, CYP3A4 metabolizes more than $60 \%$ of medicines given to human. The research on the Malaysia's population showed that there were $2,1 \%$ CYP3A4*18 (Ruzilawati et al., 2007). Mapping of the CYP3A4*1G polymorphism has not been done in Indonesia and Malaysia.

The purpose of this research is to investigate the allele and genotype frequency of CYP3A $4^{*} 1 \mathrm{G}$ on Javanese people.

\section{Materials and Methods Subjects}

The Javanese people patients that took cure in Balai Kesehatan Paru Masyarakat (BKPM) Klaten and Balai Kesehatan Paru Masyarakat (BKPM) Yogyakarta. Inclusion criteria were age $>14$ years, Javanese ethnic (three generation and over) while exclusion criteria was family relationships (father, mother, grandmother, grandfather, children and grandchildren).

\section{DNA isolation}

DNA isolation was performed by using Wizard®genomic DNA purification kit Promega, which steps were done as refered to manufacture recommendation. Briefly, $100 \mu \mathrm{L}$ of cell lysis solution was added in $300 \mu \mathrm{L}$ of buffy coat samples were incubated $10 \mathrm{~min}$. On room temperature, mix solutions were centrifuged 13.000 for 1 min. After supernatant was discarded, 300 $\mathrm{uL}$ of solution was added on the residue. The mixture was vortexed 10-15 sec. The result of the mixture was added by $1,5 \mathrm{~mL}$ of RNA solution, then was vortexed 10-15 sec. These mixtures were incubated on $37^{\circ} \mathrm{C}$ then stored in room temperature and added by $100 \mu \mathrm{L}$ of protein presipitation solution. Mixture then was vortexed on 10-15 sec and centrifuged 13.000 for $3 \mathrm{~min}$ on $37^{\circ} \mathrm{C}$. Three hundreds $\mu \mathrm{L}$ of supernatant was taken and put into $1,5 \mathrm{~mL}$ tube then added by $300 \mu \mathrm{L}$ isopropanol. The solution was mixed by inversion until the white treads-like strands of DNA form a visible mass, then centrifuged on 13.000 for $1 \mathrm{~min}$ at $37^{\circ} \mathrm{C}$. The supernatant was discarded and the residue was added by $300 \mathrm{uL}$ of $70 \%$ ethanol. It was mixed a few time and centrifuged on 13.000 for 1 min on $37^{\circ} \mathrm{C}$. The ethanol was removed after inversion. The residue was added by DNA rehydration solution $(100 \mu \mathrm{L}$ for $300 \mu \mathrm{L}$ sample volume) and incubated at $65^{\circ} \mathrm{C}$ for $60 \mathrm{~min}$. Periodically, the solution is mixed by gently tapping the tube. The samples were stored at $4^{\circ} \mathrm{C}$.

\section{Polymerase chain reaction CYP3A4*1G}

A total of $12,5 \mathrm{~mL}$ master mix , $6,5 \mathrm{~mL}$ dH2O, forward 5' - CAC CCT GAT GTC CAG CAG AAA CT-3' dan $2 \mu$ L reverse $5^{\prime}$-AAT AGA AAG CAG ATG AAC CAG AGCC-3' and $2 \mu \mathrm{L}$ DNA ( $25 \mu \mathrm{L}$ total) were mixed and run by PCR. Amplification conditions as follows: $94^{\circ} \mathrm{C}$ for $7 \mathrm{~min}$, the 35 cycles by 30 secs on $94^{\circ} \mathrm{C}, 1 \mathrm{~min}$ on $62^{\circ} \mathrm{C}$, dan 1 minon $72^{\circ} \mathrm{C}$ with 5 min final extensionat $72^{\circ} \mathrm{C}$. After PCR amplification, 8 $\mu \mathrm{L}$ of PCR products of $287 \mathrm{bp}$ was digested by $10 \mathrm{U}$ RsaI for $12 \mathrm{~h}$ at $37^{\circ} \mathrm{C}$. The digested PCR products were analyzed by electrophoresis on $2 \%$ agarose gel and detected by ethidium bromide. The bands of DNA fragments were visualized by UV light (Gao et al., 2008)

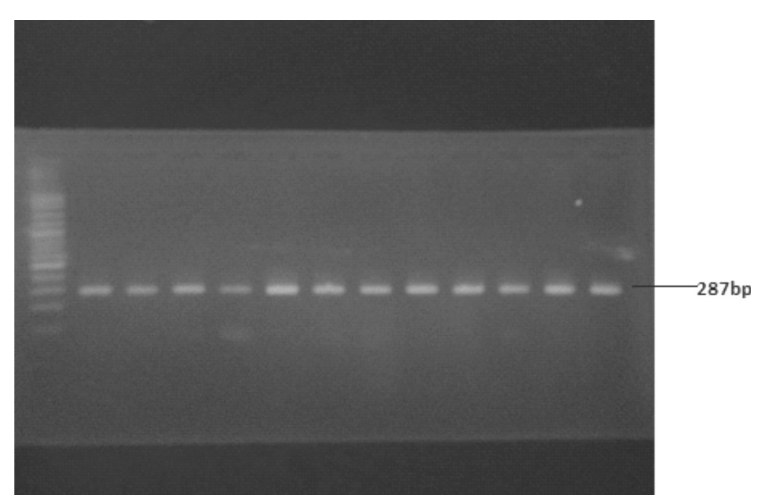

Figure 1. Electrophoregram of amplification products of CYP3A4 


\section{Results}

A total 60 subjects whom fulfilled the inclusion and exclusion criteria were used as test subjects.

The sample material was derived from blood buffy coat. The DNA purity was measured from ratio of absorbance at A260/280. The results of these samples were 1,7-2. DNA concentration was $50 \mu \mathrm{g} /$ $\mathrm{mL}$ with dilution. DNA which had isolated

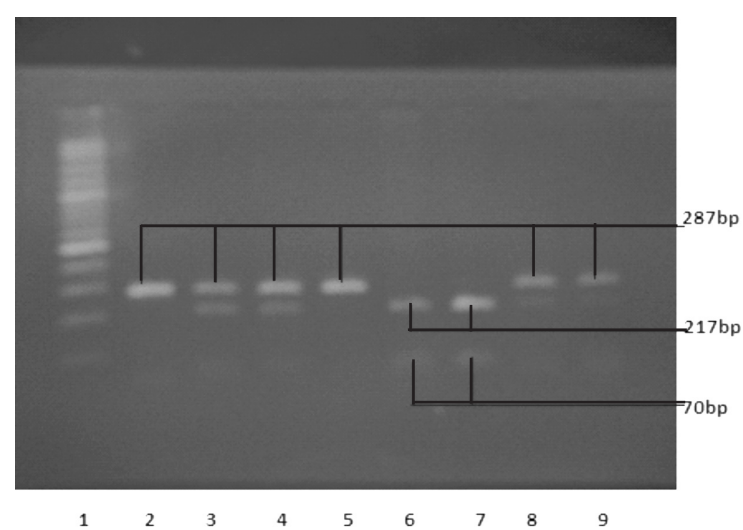

Figure 2.Detection of polymorphism in CYP3A4 ${ }^{*} 1 \mathrm{G}$ using PCR-RLFP. Lane 1 is marker $100 \mathrm{bp}$, lane2. Uncut; lane $3,4,8,9$ are from samples of CYP3A4 $* 1 /{ }^{*} 1 \mathrm{G}$ (heterozygotes); lane 5 is CYP3A4 ${ }^{*} 1 \mathrm{G} /{ }^{*} 1 \mathrm{G}$ (mutant/ variant type homozygotes) and lane 6-7 are samples of CYP3A $4 * 1 /{ }^{*} 1$ (Wild type) then amplified by RFLP- PCR. Results can be seen in Figure 1.

The digested RFLP-PCR-products that analyzed by $2 \%$ agarose gel electrophoresis is shown on Figure2.

Figure 2 shows that lanes 3,4,8, and 9 contained digested product of RFLP-PCR with size $287 \mathrm{bp}, 217 \mathrm{bp}$ and $70 \mathrm{bp}$. These are CYP3A4*1/ ${ }^{*} 1 \mathrm{G}$ (heterozygote variant type). Lane 5 (287bp) was not digested. This is homozygote variant/mutant type (CYP3A4*1G/*1G). The lane 6 and 7 shows digested product of $217 \mathrm{bp}$ and $70 \mathrm{bp}$ (wild type CYP3A4* $\left.1 /{ }^{*} 1\right)$.

The genotype and allele frequency can be seen in Table 1 and 2 .

Table 2 showed that the sum of frequency of $(G)+$ frequency $(A)=1$, and $n G^{2}+2 n G n A+n A^{2}=1$. The frequency of genotype and allele was not deviated from

Table 1. Characteristic of subject test based on sex

\begin{tabular}{|c|c|c|c|}
\hline \multirow{2}{*}{ gene } & \multicolumn{2}{|c|}{ Sex } & \multirow{2}{*}{ tota } \\
\hline & Male & Female & \\
\hline CYP3A4*1/1 & 6 & 8 & 14 \\
\hline CYP3A $4 * 1 / 1 G$ & 20 & 14 & 34 \\
\hline CYP3A4*1G/1G & 6 & 6 & 12 \\
\hline total & 32 & 28 & 60 \\
\hline
\end{tabular}

Table 2. Frequency of genotype\& allele on subject test

\begin{tabular}{|c|c|c|}
\hline Subjects & $\begin{array}{l}\text { Frequency Frequency } \\
\text { of genotype of allele }\end{array}$ & $P$ value \\
\hline CYP3A4*1G & & \\
\hline - CYP3A4*1/*1 & $14(23.3 \%)$ & \\
\hline - CYP3A4*1/*1G & $34(56.7 \%)$ & \\
\hline - CYP3A4*1G/*1G & $12(20 \%)$ & \\
\hline - Allel G (*1) & 0.52 & \\
\hline - Allel A $\left({ }^{*} 1 G\right)$ & 0.48 & \\
\hline
\end{tabular}

*test was done by Fisher's exact- test

Table 3. Frequency genotype and allele of CYP3A4*1G from the others populations:

\begin{tabular}{|c|c|c|c|c|c|c|}
\hline \multirow{2}{*}{ Populations } & \multicolumn{3}{|c|}{ frequency allele } & \multicolumn{2}{|c|}{ frequency genotype } & \multirow{2}{*}{ Ref } \\
\hline & $\mathrm{G}\left({ }^{*} 1\right)$ & $\mathrm{A}\left({ }^{*} 1 \mathrm{G}\right)$ & ${ }^{*} 1 /{ }^{*} 1$ & ${ }^{*} 1 /{ }^{*} 1 G$ & ${ }^{*} 1 \mathrm{G} /{ }^{*} 1 \mathrm{G}$ & \\
\hline Javanese & 0.53 & 0.47 & 0.25 & 0.55 & 0.20 & This study \\
\hline China & 0.724 & 0.276 & 0.51 & 0.43 & 0.06 & Gao et al., 2008 \\
\hline China & 0.75 & 0.25 & 0.58 & 0.34 & 0.08 & Dong et al., 2011 \\
\hline
\end{tabular}


Hardy-Weinberg equilibrium on p. 1,000. The comparison of this study with research in Chinese population can be seen in Table 3.

\section{Discussion}

The result of this study showed that the frequency of polymorphism of CYP3A $4 * 1 /{ }^{*} 1$ was $0,25, \mathrm{CYP} 3 \mathrm{~A} 4 * 1 /{ }^{*} 1 \mathrm{G}$ was 0,55 and CYP3A4*1G/* $1 \mathrm{G}$ was 0,20 . Frequency of allele $G$ was 0,53 , while the frequency of allele A was 0,47 . By comparing to two studies on Chinese populations, it showed that the frequency of variant type/mutant type CYP3A4* $1 \mathrm{G} /{ }^{*} 1 \mathrm{G}$ of Javanese population is much higher than Chinese population. The result of the genetics findings is diferent from anthropological studies. Anthropological studies states that the island of Java had inhabited by Homo sapiens since 40,000 years ago. The earliest inhabitants were austromelanesid ethnic that since 10.000 years ago were mongolidizied. This process became more intensive during last 1000 years. The Javanese were formed since 2168 years ago (Glinka, 2006), so there is a relationship between Mongolian and Javanese ethnics. The frequency of mutant/ variant type in this research is relatively large (55\% in heterozygotes and $20 \%$ homozygous of CYP3A4*1G/ $\left.{ }^{*} 1 G\right)$.

CYP3A $4 * 1 G$ was determined by the substitution of $82266 \mathrm{G}>\mathrm{A}$. Location of this variant is in intron 10 of the CYP3A4 gene. It was resulted in the change of amino acid from isoleusin into valin (I369V). Both of these amino acids have different polarity levels and molecular weight. The molecular weight of isoleucine (C6H13NO2) is $131.1736 \mathrm{~g} / \mathrm{mol}$, while molecular weight of valine $(\mathrm{C} 5 \mathrm{H} 11 \mathrm{NO} 2)$ is $117.1469 \mathrm{~g} / \mathrm{mol}$. The amino acid with different unit's nature will reduce the catalyzing ability of cytochrome enzyme (CYP3A4) (Gao et al., 2008). Thus, the effects of CYP3A4*1G polymorphism is vary. After atorvastatin given, the mean percent reduction of total cholesterol plasma in individual with CYP3A $4{ }^{*} 1 /{ }^{*} 1$ is $16,83 \pm 3 \%, 17,8 \pm 3,8 \%\left({ }^{*} 1 /{ }^{*} 1 \mathrm{G}\right)$ and $20,9 \pm 5,0 \%$ $\left({ }^{*} 1 \mathrm{G} /{ }^{*} 1 \mathrm{G}\right)$. Conversely, a decreasing in total cholesterol on simvastatin therapy showed no difference among these three variants (Gao et al, 2008). Yuan et al (2011) states that individual with variation of CYP3A $4 * 1 G /{ }^{*} 1 G$ has a lower metabolic rate of fentanyl than type CYP3A $4 * 1 /{ }^{*} 1 G$ and CYP3A $4{ }^{*} 1 /{ }^{*} 1$. The fentanyl plasma levels of individual with CYP3A $4 * 1 /{ }^{*} 1(12,8$ $\pm 6,5 \mathrm{ng} / \mathrm{mL}$ ) was significantly lower than CYP3A4*1/*1G (16,8 \pm 9,0 ng/mL, p<0,01) and lower than individual with variant type CYP3A4*1G/*1G ( 28,1 $\pm 9,5 \mathrm{ng} / \mathrm{mL}, \mathrm{p}<0,01)$ (Yuan et al., 2011). Variation effect of this polymorphism could occured because of the substitution of guanine by adenine that occured at 82266 (G82266A) in variant type CYP3A $4 * 1 G /{ }^{*} 1 G$, which causes a change from isoleucine to valine (I $369 \mathrm{~V}$ ) (Gao et al., 2008). This amino acid change would reduce the ability of catalyzing cytochrome (CYP3A4) which may causes plasma drugs levels becoming higher. Therapy of drugs which are substrates of CYP3A4 together with other drugs, which both are inductor and inhibitors of CYP3A4, should also be tested to predict its effects.

Based on this result, therapy of drugs which are substrates of CYP3A4 must be carried carefully. Several drugs had been known as inhibitors and inductors. The drugs known as inductors CYP3A4 such as antiepileptic drugs (classphenobarbital, phenytoin, carbamazepine, felbamate, lamotrigine, oxcarbazepine, primidone, rufinamid \& topiramate), cyclophospamid, dexamethason, erythromisin, griseofulvin, lansoprazole, nevirapin, omeprazol, pioglitasone, prednisone, rifampin,troglitason. The drugs known as inhibitor of CYP3A4 are chlorampenicol, cimetidin, cyprofloxasin, flukonazole, itrakonazole, nevirapin, norfloxasin, varikonazole, mibefradile, estradioleand (Tomaszewski et al., 2008). Therapy of drugs which are substrates of CYP3A4 together with its inhibitor may increase drugs plasma level. This can cause adverse effect. Conversely, the therapy of drugs that are substrates of CYP3A4 together with its 
inductor may decrease drugs plasma level and can cause failure of the treatment.

As the conclusion, the frequency of CYP3A $4 * 1 G$ in Javanese people were 0,25 for CYP3A4*1/*1, 0,55 for CYP3A4*1/ ${ }^{*} 1 G$, and 0,20 for CYP3A $4 * 1 G /{ }^{*} 1 G$. Frequency of allele $\mathrm{G}$ was 0,53 while allele A was 0,47. Allele and genotype frequency of Javanese people were still in Hardy-Weinberg equilibrium.

\section{References}

Alvirevi, A., Park, B.K., and Pirmohamed, M. 2006. Pharmacogenetic of adverse drugs reactions in Hall, IP and Pirmohamed, M, Pharmacogenetics, pp. 1-78, Taylor and Francis Group, New York, USA

Dong, Z-L., Li,H., Chen,Q-X, Hu,Y., Wu,S.J., Tang,L-Y., Gong,W-Y., Xie,G-H., and Fang, X-M., 2011. Effect of CYP3A4*1G on the fentanyl consumption for intravenous patient-controlled analgesia after total abdominal hysterectomy in Chinese Han population. J. of Clin. Pharm. and Ther., 36(4)

Gao, Y., Zhang, L.R., and Fu, Q., 2008. CYP3A $4 * 1 G$ polymorphism is associated with lipid-lowering efficacy of atorvastatin but not simvastatin. Eur. J. Clin. Pharmacol., 64, 877-882

Glinka, J., 2010.Asalmula orang Jawa: suatu tinjauan anthropologis.Jurnal Masyarakat Kebudayaan dan Politik. 14(2), 1-8

Hsieh, K.P., Lin, Y.Y., Cheng, C.L., Lai, M.L., Lin, MS., Siest, J.P., and Huang, J.D., 2001. Novel mutations of CYP3A4 in Chinese. D. Metab. Dispos.,29(3), 268-273

Ruzilawati, A.B., Suhaimi, A.W.M., and Gan, S.H., 2007. Genetic polymorphism of CYP3A $4 * 18$ allele is found in five health Malaysian subjecs. Clin. Chim. Acta., 383(1-2), 158-162

Tomaszewski, P., Tomaszewski, G.K., and Pachecka, J.,2008. Cytokhrome P450 polymorphism-molecular, metabolic, and pharmacogenetic aspects. II. Participation of CYP isoenzymes in the metabolism of endogenous subatances and drugs. Drug Res., 65(3), 307-318
Van Schaik, R.H.N., Wildt, SNd., van Iperen, N.M., Uitterlinden, A.G., van de Anker, J.N., \& Lindemans, J., 2000. CYP3A4-V polymorphism detection by PCR-Restriction fragment lenght polymorphism analysis and its allelic among 199 dutch caucasians. Clin. Chem. Acta., 46, 1834-1836

Yuan, R., Zhang, X., Deng, Q., Wu, Y., Xiang, G., 2011.Impact of CYP3A4*1G polymorphism on metabolism of fentanyl in Chinese patients undergoing lower abdominal surgery. Clin. Chem. Acta., 412(9-10), 755-60.

Wang, A., Yu, B.N., Luo, C.H., Tan, R.Z., Zhou, G., Wang, L.S., Zhang, W., Li, Z., Liu, J., and Zhou, HH., 2005. Ile118Val genetic polymorphism of CYP3A4 and its effect on lipid lowering efficacy of simvastatin in Chinese hyperlipidemic patienst. Eur. J. Clin. Pharmacol. 64, 877-882 